\title{
Iron Loss Calculation Method of Filter Inductor Core on a Single-Phase PWM Voltage Source Inverter
}

\author{
Seiji IyasuＳtudent Member (Tokyo Metropolitan University, iyasu@pe.eei.metro-u.ac.jp) \\ Toshihisa Shimizu Senior Member （Tokyo Metropolitan University, shimizu@eei.metro-u.ac.jp) \\ Ken-ichiro Ishii Member (TOHO ZINC, ishii-kenichiro@toho-zinc.co.jp)
}

Keywords: PWM inverter, filter-inductor, iron loss, dynamic minor loop, loss map, iron loss calculation method

In order to increase both the conversion efficiency and the power density of the power converters, a study on the loss reduction method on the magnetic component is one of the most important issue among the power electronics authorities. Traditionally, reduction methods of the magnetizing loss of the transformers and the ac motors have been studied. However, only a few papers have been reported the inductor iron loss of the ac/dc filter inductor under the use of the high-frequency PWM switching condition. In this case, the magnetic trajectory on the BH-plane has two kind of the magnetic loops. The one is caused by the low-frequency current which depends on the output current and another is caused by the highfrequency ripple current which depends on the modulation condition of the inverter. In this paper, the former magnetic loop is called a major loop and the later magnetic loop is called a dynamic minor loop. Also, it is well known that the magnetic operating point and the shape of dynamic minor loop are changed according to the instantaneous amplitude of the low-frequency current. Especially, in the case when the switching frequency is much higher than the output frequency, the loss caused by dynamic minor loops (the highfrequency ripple current) usually dominate the iron loss of the inductor. Hence the loss calculation on the inductors are usually complicated compared to that on the transformers.

The authors have reported a novel loss map of magnetic materials as shown in Fig. 1. By using this loss map, we can calculate the iron loss on the inductors in many kinds of converters. In the case when we calculate the iron loss on the inductor on DC-DC converters, it is enough to multiply the data on the loss map the switching frequency and the volume of the core. Furthermore, we have proposed a novel iron loss calculation method of the ac filter inductor on the PWM inverter by using the loss map. This method enables to calculate the iron loss caused by the dynamic minor loops by using the loss map and executing the easy circuit-simulation. The relation between the control method for the PWM inverter and the iron loss is discussed. The effectiveness of this method is verified through $500 \mathrm{~W}$ experimental set-up. Fig. 3 shows the comparison of the iron loss caused of the experimental results and the calculation results. It is clear that the calculation results are good agreement with the experimental results.

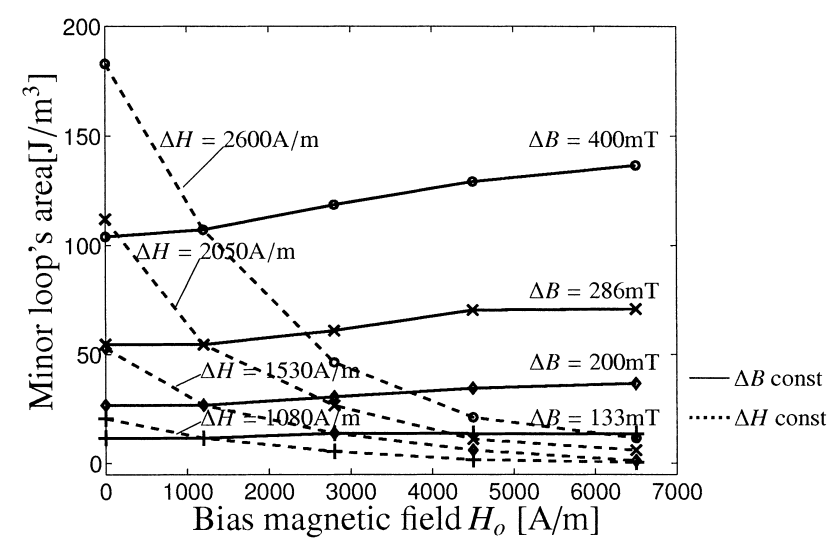

Fig. 1. Loss map of the magnetic material (SK-core)

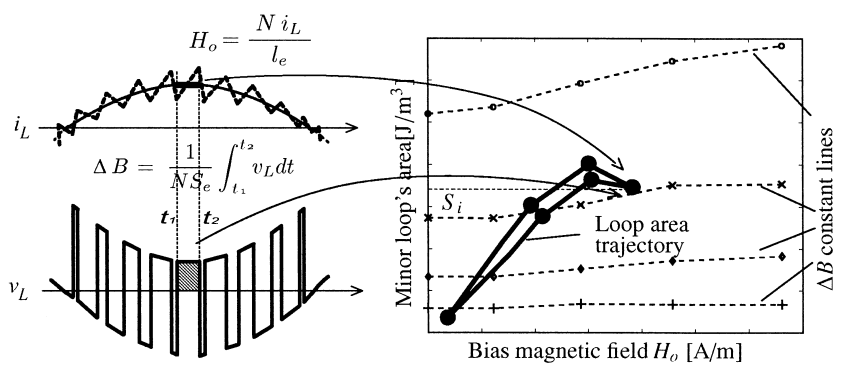

Fig. 2. Iron loss calculation method on PWM inverters

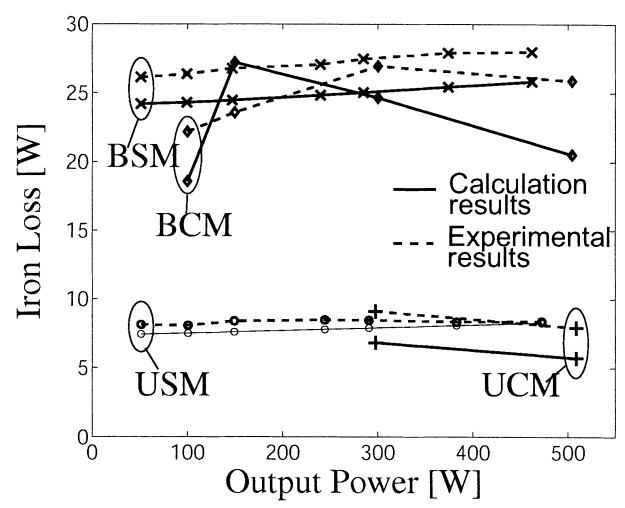

Fig. 3. Comparison of experimental result and calculation result 


\title{
単相電圧形PWM インバータ回路用フィルタリアクトルの 鉄損算定法
}

\author{
学生員 居安 誠二* ${ }^{*}$ 上級会員 清水 敏久* \\ 正 員 石井謙市朗**
}

\section{Iron Loss Calculation Method of Filter Inductor Core on a Single-Phase PWM Voltage Source Inverter}

Seiji Iyasu*, Student Member, Toshihisa Shimizu*, Senior Member, Ken-ichiro Ishii**, Member

The authors have reported a novel iron loss calculation method based on a loss-map of the magnetic materials. A distinctive feature of this method is that the iron loss on the inductors can easily be calculated in many kinds of converters. In this paper, a novel iron loss calculation method of the ac filter inductor on the PWM inverter by using the loss-map is described. This method enables to calculate the iron loss due to the dynamic minor loops by using the loss map and executing the easy circuit-simulation. The relation between the control method for the PWM inverter and the iron loss is discussed. Finally, the effectiveness of this method is verified through $500 \mathrm{~W}$ experimental set-up.

キーワード：PWM インバータ，フィルタリアクトル，鉄損，動的マイナーループ，ロスマップ，鉄損算定法

Keywords: PWM inverter, filter-inductor, iron loss, dynamic minor loop, loss map, iron loss calculation method

\section{1. まえがき}

半導体電力変換器の高パワー密度化は, その適用範囲の 多様化やエネルギーの有効活用の観点から大きな期待が寄 せられている(1)。スイッチング周波数の高周波化は, 半導 体電力変換器のなかで多くの体積・重量を占めるトランス . リアクトルの小形・軽量化という観点から高パワー密度化 に有用であるが，磁性材料の損失増加が懸念されている。 半導体電力変換器で使用するトランス・リアクトルの磁性 材料では，スイッチングに伴うリプル電流成分に対応して， $\mathrm{BH}$ 平面上の多様な場所にローカルな磁気ヒステリシスルー プ（以下，「動的マイナーループ」と呼称する）が発生し, 鉄損増加の原因となる。変換器の高周波化が進むことによ り, この動的マイナーループの発生数が増え, また渦電流 損などの高周波特有の損失も加わって, 鉄損が著しく増加 する。将来の高パワー密度化された電力変換器では, 変換 器の全損失のうち, 鉄損が大きな割合を占めると考えられ る。したがって，動的マイナーループに起因する鉄損の算 定法や鉄損低減手法の開発は重要な技術課題となっている。

\footnotetext{
* 東京都立大学 工学研究科 電気工学専攻

干 192-0397 東京都八王子市南大沢 1-1

Department of Electrical Engineering, Tokyo Metropolitan University

1-1, Minamiosawa, Hachioji, Tokyo 192-0397

** 東邦覀鉛 (株) 技術開発本部 開発部/知的財産部

干 103-8437 東京都中央区日本橋本町 1-6-1

Technology and Development Div., Toho Zinc Co., Ltd.

1-6-1, Nihonbashi-honcho, Chuo-ku, Tokyo 103-8437
}

従来から提案されている鉄損算定法は “Steinmetz Equation”を改良した方式(2)(3) と“Preisach Model”を拡張した方 式 (4)に代表される。矩形波交流電圧や PWM 波交流電圧で 磁性体を励磁する变圧器や交流電動機の場合には, その励 磁電流は印加電圧で一義的に決定されるので, 前者の手法 を用いて, 従来の正弦波電圧励磁時の鉄損データから概ね 妥当な精度で鉄損の值を計算出来る。しかし, DC-DCコン バータやPWM インバータに使用されるフィルタリアクト ルの場合には, BH 平面上に形成される動的マイナールー プが負荷電流に依存した励磁状態によって多様に変化する ので，この方法では鉄損算定は極めて困難である。後者の “Preisach Model”を拡張した方式は, 特定の励磁状態につ いて動的マイナーループ形状を数式モデル化して，ループ 面積を予測する。個々の励磁条件について数式モデルのパ ラメータを設定する煩雑さはあるが，DC-DC コンバータ 用フィルタリアクトルについては鉄損算定が原理的には可 能と思われる。しかし, PWM インバータ用フィルタリア クトルのように, 交流出力の一周期間において, 動的マイ ナーループの形状が逐次変化する場合には, 算定手順が極 めて煩雑になり実用性に乏しいものと考える。このような 状況にあって, PWM 変調されたインバータで励磁される 交流電動機やトランスの鉄損に関してはいくつか報告がな されているが(6) (9), フィルタリアクトルの鉄損に関しては, 本論に示すスイッチング毎に発生する動的マイナーループ を評価する手法も含めて, 筆者らの知る限りきわめて少な いように思われる。

筆者らはすでに, PWM インバータ用リアクトルの鉄損 
の評価を行い(10)(11)，PWM インバータの制御・変調方式の 違いにより動的マイナーループの発生状況が大きく異なり, 鉄損・電力变換効率に大きな違いが出ることを見出してい る。さらに, 動的マイナーループを実験的に評価し, PWM インバータ用リアクトルの鉄損算定法について基礎的検討 を行ってきた ${ }^{(12)}$ 。

本稿は，PWM インバータ用リアクトルの鉄損算定法を 示し, 鉄損低減手法の提案を目的としている。始めに, フィ ルタリアクトルの動的マイナーループと鉄損について論じ, 筆者らが提案している磁性体ロスマップと PWM インバー タ用リアクトルの鉄損算定法を示す。提案した鉄損算定法 を用いれば，磁性体ロスマップと理想リアクトルによる簡 易的なシミュレーションで PWM インバータ用リアクトル の鉄損が容易に計算できることを示す。次に，代表的な制 御方式であるサブハーモニック変調と電流ヒステリシス制 御をとりあげ，それぞれについて，電圧レベル数の異なる バイポーラ変調とユニポーラ変調とを組み合わせた合計 4 種類の変調制御方式について，本稿の鉄損算定法を用いて 鉄損を計算し，制御・変調方式と鉄損の值との関係を考察 する。さらに, 出力 $500 \mathrm{~W}$ の PWM インバー夕実験装置を 用いて，鉄損と銅損，電力変換効率を測定すると共に，損 失分析を行い，提案した鉄損算定法の有用性を示す。最後 に同一の材質で体積の異なるコアを用いて設計したリアク トルの鉄損について，鉄損算定值と実験值の両面から比較 する。動作時の最大磁束密度を通常よりも大きくすること で，コアの体積・重量を減少でき，同等の電力変換効率が 得られることを示す。

\section{2. ロスマップを用いた鉄損算定法}

〈2・1〉 動的マイナーループ 半導体電力変換器に用 いられるフィルタリアクトルでは，リプル電流成分に伴っ て，BH 平面上に動的マイナーループが発生し，鉄損とな る。筆者らは降圧チョッパ回路用いて, 動的マイナールー プをフィルタリアクトルに発生させ，評価を行っている ${ }^{(12)}$ 。 降圧チョッパ回路のフィルタリアクトルは矩形波電圧で励 磁されるため，リアクトル電流は DC 電流にリプル成分が 重畳した電流になる。これにより, 磁界 $H$, 磁束密度 $B$ は $\mathrm{DC}$ バイアスにリプル成分が重畳した波形となり，リアクト ルのコア材の $\mathrm{BH}$ 平面上に図 1 に示すような動的マイナー ループが発生する。この動的マイナーループを決定する主 なパラメータは磁束密度リプル $\Delta B$, 磁界リプル $\Delta H$, バイ アス磁界 $H_{o}$ である。動的マイナーループの面積にスイッ チング周波数 $f_{s}$ とコアの体積 $V_{e}$ を乗算した值が鉄損 [W] となる。図 2 に動的マイナーループ・鉄損測定システムを 示す。二次巻線により磁束密度検出を行い, 電流検出によ り磁界検出を行う。動的マイナーループ・鉄損を正確に測 定するには，リアクトル電流の位相を高精度で検出する必 要がある (5)。本測定システムでは，BH アナライザの補正 機能を利用することにより電流検出器の位相誤差を抑制し, 高精度の磁界検出を実現しており，高精度な動的マイナー ループ・鉄損が評価可能である。

図 3 に今回評価する鉄心材料である SK 材 (東邦覀鉛製)

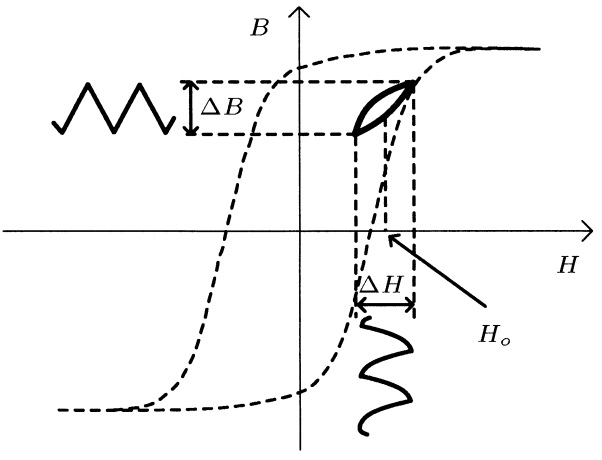

図 1 動的マイナーループ

Fig. 1. Dynamic minor loop.

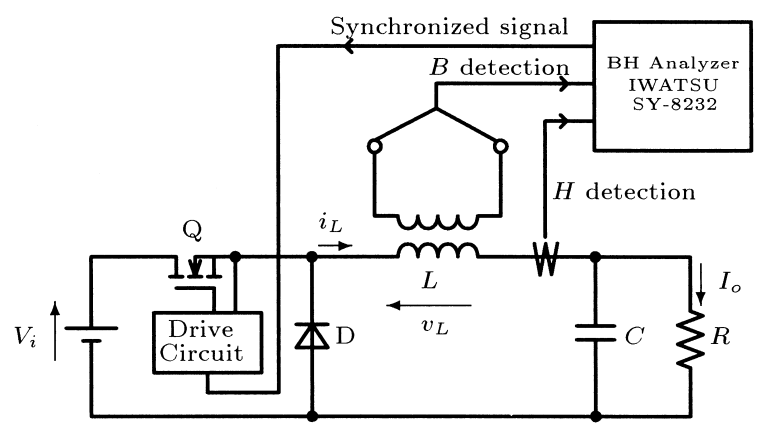

図 2 動的マイナーループ測定システム

Fig. 2. Mesuring system for dynamic minor loop.

の動的マイナーループの測定結果を示す。バイアス磁界 $H_{o}$ を $1230 \mathrm{~A} / \mathrm{m}$ から $6500 \mathrm{~A} / \mathrm{m}$ まで変化させて $\Delta B$ 一定あるい は $\Delta H$ 一定にして測定を行った。なお， $\Delta B$ 一定の条件で は, 磁束密度の変化が一定になるように入力電圧 $V_{i}$ および チョッパの通流率をほぼ一定に保ったまま，負荷抵抗の值 を調整して $H_{o}$ を変化させて，動的マイナーループを測定 した。また， $\Delta H$ 一定の条件では，リプル電流が一定とな るように入力電圧 $V_{i}$ とチョッパ通流率を調整しつつ, 負荷 抵抗の值を調整して $H_{o}$ を変化させて, 動的マイナールー プを測定した。

図 3(a)，(b) は， $\Delta B$ 一定の条件でバイアス磁界 $H_{o}$ が変 化したとき，および図 3(a), (c) は $\Delta H$ 一定の条件でバイア ス磁界 $H_{o}$ が変化したときの動的マイナーループの変化の 様子を示している。バイアス磁界 $H_{o}$ の変化に対して， $\Delta B$ 一定の条件, $\Delta H$ 一定の条件では, 動的マイナーループの 形状・面積の変化が全く異なることがわかる。

〈2・2〉磁性体ロスマップ 図 4 に筆者らが提案して いる磁性体ロスマップを示す。ただし，図 4 は今回評価す る鉄心材料である SK 材 (東邦亜鉛製) のロスマップであ る。このロスマップは磁界強度リプル $\Delta H$, 磁束密度リプ ル $\Delta B$ をパラメータとし, バイアス磁界 $H_{o}$ に対する動的マ イナーループ面積の值を示すものである。 $\Delta H$ または $\Delta B$, $H_{o}$ に応じて, 動的マイナーループ面積の変化の状況が図 4 で規定されることが分かる。 $\Delta B$ または $\Delta H$, バイアス磁界 $H_{o}$ ，スイッチング周波数 $f_{s}$ は簡単に計算できるため，この ロスマップを用いることにより, 様々な動作条件の DC-DC 


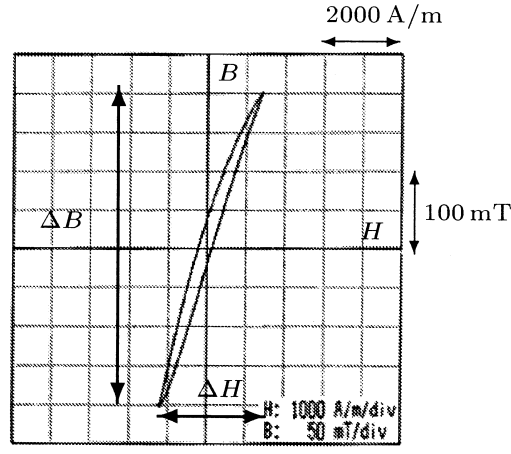

(a) $\Delta B=400 \mathrm{mT}, \Delta H=2600 \mathrm{~A} / \mathrm{m}$, $H_{o}=1230 \mathrm{~A} / \mathrm{m}$.

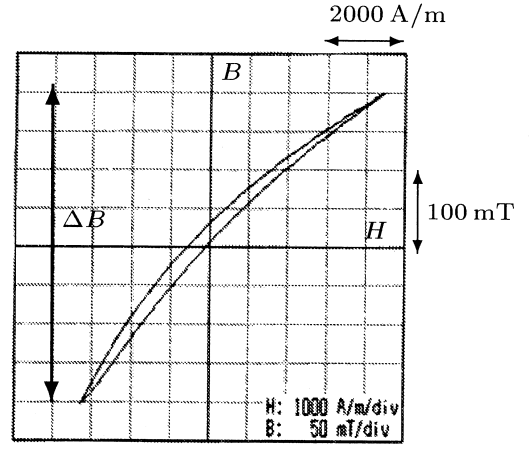

(b) The "constant $\Delta B$ " condition $\left(\Delta B=400 \mathrm{mT}, H_{o}=6500 \mathrm{~A} / \mathrm{m}\right)$.

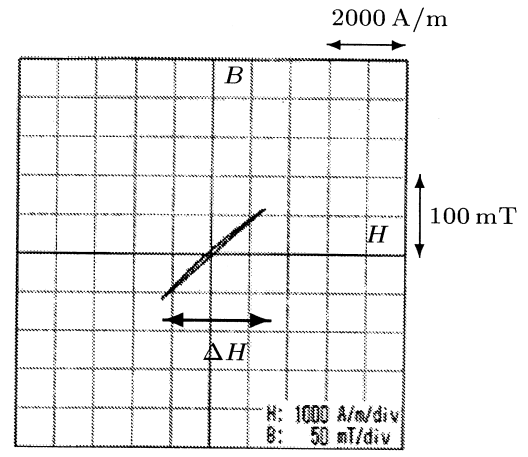

(c) The "constant $\Delta H$ " condition $\left(\Delta H=2600 \mathrm{~A} / \mathrm{m}, H_{o}=6500 \mathrm{~A} / \mathrm{m}\right)$

図 $3 \Delta H$ 一定時と $\Delta B$ 一定時の動的マイナーループの測定結果

Fig. 3. Dynamic minor loops when $\Delta H$ kept constant and $\Delta B$ kept constant.

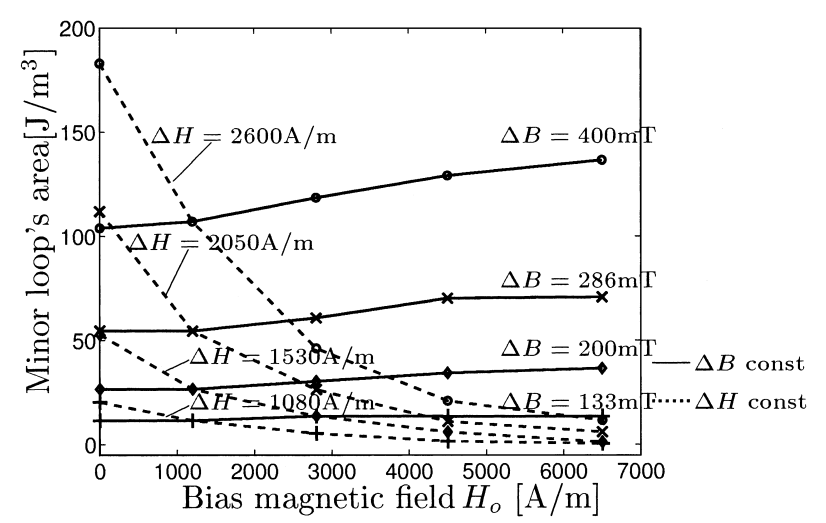

図 4 磁性体ロスマップ（SK 材）

Fig. 4. Loss map of the magnetic material (SK-core).

コンバータ用フィルタリアクトルの鉄損が算定できる。た だし，高周波特有の損失である渦電流損・残留損が無視で きなくなる高周波帯域では，動的マイナーループの面積が 増加すると考えられるので，このロスマップに加えて周波 数変化に伴う面積増加の係数を加味する必要がある。この ような周波数帯域での動的マイナーループの評価は稿を改 めて報告したい。

〈2·3〉 PWM インバータ用リアクトルの鉄損算定法

出力周波数 $f_{o}$ に対してスイッチング周波数 $f_{s}$ が十分 に高い場合，PWM インバータ用リアクトルには正弦波に 三角波状のリプル電流が重畳した電流が流れるため, 正弦 波 (基本波) 成分の鉄損とリプル成分の鉄損が発生する。基 本波成分による鉄損がメジャーヒステリシスループによる 鉄損に相当し，リプル成分による鉄損が動的マイナールー プによる鉄損に相当する。通常，正弦波励磁時における鉄 損データは磁性体メーカのデータシートに記載されている ためメジャーヒステリシスループによる鉄損の算定は容易 であるが，動的マイナーループによる鉄損はデータが示さ れていないので損失の計算は困難である。

図 5 に単相 PWM インバータの回路図を, 図 6 に単相 PWM インバータの動作波形とフィルタリアクトルに加わ るパルス電圧 $v_{L}$ の 3 周期分の動的マイナーループを示す。

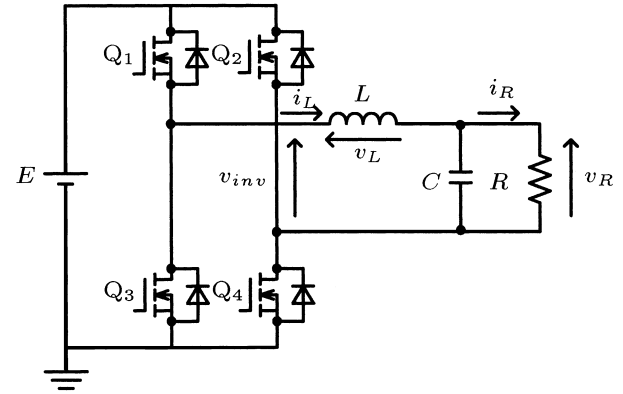

図 5 単相 PWM インバータ

Fig. 5. Single phase PWM inverter.

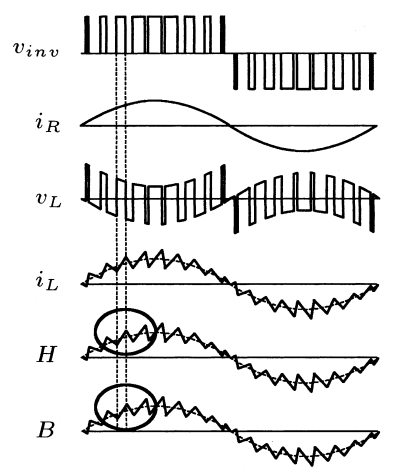

(a) Operation waveforms.

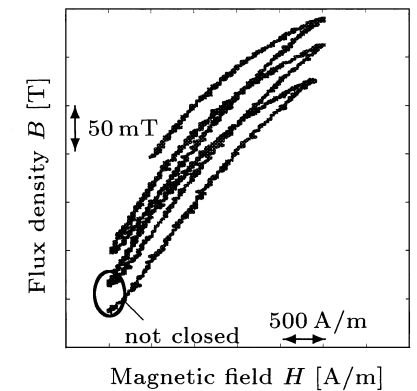

(b) Dynamic minor loops.
図 $6 \mathrm{PWM}$ インバータの動作波形と動的 マイナーループ

Fig. 6. Operation waveforms and dynamic loop on PWM inverter.

図 6(a)に示すように, フィルタリアクトルには端子電圧 $v_{L}$ のパルス電圧が加わると共に, 負荷電流 $i_{R}$ に依存してリア クトル電流 $i_{L}$ が流れる。そのため, リアクトルに加わるバ イアス磁界は出力電流周期で時間的に変化し, 図 6(b) に示 すように動的マイナーループはオープンループになり，鉄 損算定が困難になる。

図 7 に $\Delta B, H_{o}$ が $235 \mathrm{mT}, 2000 \mathrm{~A} / \mathrm{m}$ における，1 パル ス周期分の降圧チョッパ時と PWM インバータ時の動的マ イナーループを示す。図 7(b) のマイナーループはオープ 


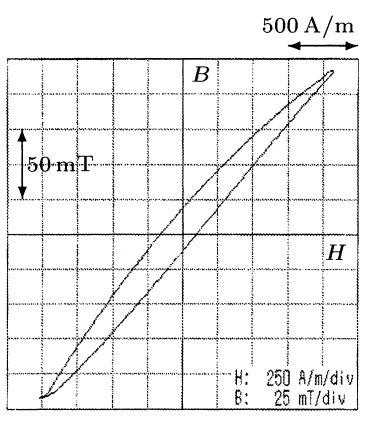

(a) Under buck chopper circuit.

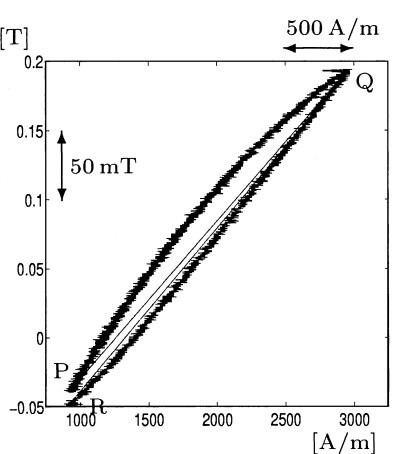

(b) Under the PWM inverter.
図 $7 \Delta B=235 \mathrm{mT}, H_{o}=2000 \mathrm{~A} / \mathrm{m}$ 時の動的 マイナーループ

Fig. 7. Dynamic minor loops when $\Delta B=235 \mathrm{mT}, H_{o}=$ $2000 \mathrm{~A} / \mathrm{m}$.

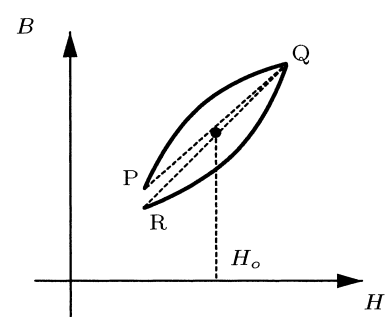

(a) Dynamic minor loop on PWM

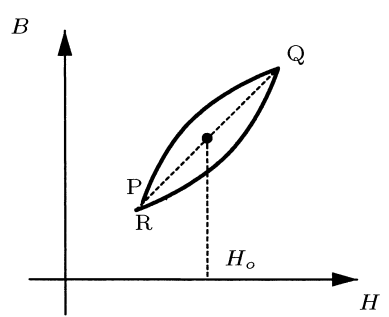

(b) Quasi-closed loop. inverter at one switching period

図 8 準クローズループヘの近似法

Fig. 8. Approximation to the quasi-closed loop.

ンループではあるが，形状が図 7(a) と類似していること がわかる。図 8 のようにこのオープンループを準クローズ ループに置き換えることでスイッチングリプル分の鉄損を 近似する。動的マイナーループの $\Delta B$ がコア材の飽和磁束 密度よりも十分に小さい場合, 無損失のリアクトルであれ ば，動的マイナーループは直線 $\mathrm{PQ}$ と直線 $\mathrm{QR}$ を描く。し たがって直線 $\mathrm{PQ}$ と直線 QR から膨らんだ曲線部分の面積 がスイッチングリプルによる鉄損に相当すると考えられる。 また, 出力周波数に対して, スイッチング周波数が十分に 大きければ，P 点と R 点は近接するので，図 8(b) の準ク ローズループの面積とチョッパ時の動的マイナーループの 面積はほぼ同じになるはずである。実際に, 図 7(a) と (b) の面積はそれぞれ $41.6 \mathrm{~J} / \mathrm{m}^{3}, 41.4 \mathrm{~J} / \mathrm{m}^{3}$ であり，ほぼ一致 した。この結果は, PWM インバータの出力線間電圧パル ス 1 周期分の動的マイナーループの面積が前節に示したロ スマップから参照できることを示している。

これらの成果を用いて, 筆者らは図 9 に示すような PWM インバータ用リアクトルの鉄損算定法を提案している。半 出力周期の期間に対して, 各々の出力線間電圧パルス周期 における $\Delta B, H_{o}$ を次式により計算する。

$$
\begin{aligned}
\Delta B & =\frac{1}{N S_{e}} \int_{t_{1}}^{t_{2}} v_{L} d t \\
H_{o} & =\frac{N \hat{i_{L}}}{l_{e}} \ldots \ldots \ldots
\end{aligned}
$$

ここで, $N$ はリアクトルの巻数, $S_{e}, l_{e}$ はコア材の断面

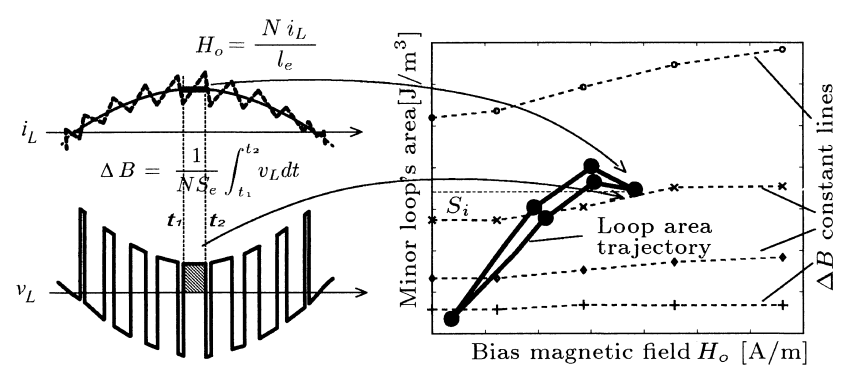

図 9 PWM インバータ用リアクトルの鉄損算定法

Fig. 9. Iron loss calculation method on PWM inverters.

積と磁路長, $\hat{i_{L}}$ は各スイッチング期間におけるリアクトル 電流の平均值である。

図 9 に示すように，計算したスイッチング毎の $\Delta B, H_{o}$ を用いて, 提案したロスマップにプロットし, スイッチン グ毎の動的マイナーループ面積 $S_{i}$ を決定する。図 9 にお いて, “・”はスイッチング毎の動的マイナーループ面積を 示している。次式のように，このプロットされた点“・”か ら動的マイナーループ面積の合計を取り, コアの体積 $V_{e}$ と 出力周波数 $f_{o}$ を乗算した值を 2 倍することにより，スイッ チングリプルにおける鉄損 $P[\mathrm{~W}]$ が算定できる。

$$
P=2 \cdot V_{e} \cdot f_{o} \cdot \sum_{i=1}^{n} S_{i}
$$

ここで $n$ は, 出力半周期間におけるインバータ出力線間 電圧のパルス数（すなわち動的マイナーループ数）である。

(1) 式より， $\Delta B$ の計算では, 非線形要素であるインダク タンス $L$ や透磁率 $\mu$ を必要としない。また $H_{o}$ は出力電流 に依存して決まる。これらのことから， $\Delta B, H_{o}$ は理想り アクトルを用いたシミュレーションにより計算できる。し たがって，この鉄損算定法はロスマップと簡易的なシミュ レーションを行うことにより実行できる。各スイッチング 期間に発生する動的マイナーループ面積の值を図 9 のロス マップ上に“・”で記載すると, その位置は出力電流の変化 に伴って移動する。この移動する軌跡をループ面積軌跡と 呼ぶことにする。本稿では, このループ面積軌跡を評価す ることで, 制御・変調方式における鉄損の違いを考察する。

ここで， $\Delta B$ の代わりに $\Delta H$ を用いる場合には次式を用 いればよい。ただし，この場合には非線形要素である透磁 率 $\mu$ の変動を考慮する必要がある。

$$
\Delta H=\frac{1}{\mu} \Delta B=\frac{1}{\mu N S_{e}} \int_{t_{1}}^{t_{2}} v_{L} d t
$$

\section{PWM インバータの制御方式と鉄損の計算結果}

〈3・1〉 鉄損の計算条件前章の鉄損算定法を用いて PWM インバータのフィルタリアクトルのスイッチングリ プル，すなわち動的マイナーループによる鉄損を計算する。 インバータの制御・変調方式はユニポーラモード・サブハー モニック変調（以下 USM), バイポーラモード・サブハー モニック変調 (以下 BSM), ユニポーラモード・電流ヒス テリシス制御 (以下 UCM), バイポーラモード・電流ヒス 
表 1 回路定数

Table 1. Circuit parameters.

\begin{tabular}{l|c}
\hline \hline Input Voltage $E$ & $180 \mathrm{~V}$ \\
\hline Output Filter Inductance $L$ (Fig.10) & $1 \mathrm{mH}$ \\
\hline Output Filter Capacitance $C$ & $20 \mu \mathrm{F}$ \\
\hline Cut-off Frequency $f_{c}$ & $1 \mathrm{kHz}$ \\
\hline Output Frequency $f_{o}$ & $50 \mathrm{~Hz}$ \\
\hline Output Pulse Frequency $f_{s}$ & $10 \mathrm{kHz}$ \\
\hline Output voltage $v_{R}$ & $100 \mathrm{~V}$ \\
\hline
\end{tabular}

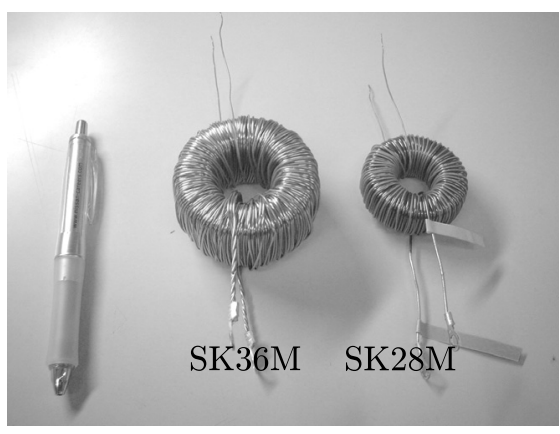

図 10 評価対象リアクトル

Fig. 10. Inductors for experiment and calculation.

表 2 評価リアクトルの仕様

Table 2. Specification of Inductors.

\begin{tabular}{l|c|c}
\hline \hline & SK36M & SK28M \\
\hline Core Material & Iron Powder & Iron Powder \\
\hline Effective Magnetic Path Length $l_{e}$ & $139.81 \mathrm{~mm}$ & $108.394 \mathrm{~mm}$ \\
\hline Effective Cross Sectional Area $S_{e}$ & $332.94 \mathrm{~mm}^{2}$ & $114.879 \mathrm{~mm}^{2}$ \\
\hline Volume $V_{e}$ & $46546 \mathrm{~mm}^{3}$ & $12452 \mathrm{~mm}^{3}$ \\
\hline Weight $M$ & $340 \mathrm{~g}$ & $90 \mathrm{~g}$ \\
\hline Turn $N$ & 69 turn & 103 turn \\
\hline Inductance $L$ & $1 \mathrm{mH}$ & $1 \mathrm{mH}$ \\
\hline Maximum flux density $B_{\max }$ & $0.83 \mathrm{~T}$ & $1.07 \mathrm{~T}$ \\
\hline
\end{tabular}

テリシス制御（以下 BCM）を用いた。なおサブハーモニッ ク変調では正弦波一三角波比較方式を，電流ヒステリシス 制御ではリアクトル電流を検出したヒステリシス制御を用 いている。UCM はスイッチ $\mathrm{Q}_{1}, \mathrm{Q}_{3}$ を出力周波数の正弦波 指令值信号に同期させ，スイッチ $\mathrm{Q}_{2} ， \mathrm{Q}_{4}$ をヒステリシス 制御することで実現した。表 1 にシミュレーションの回路 定数を示す。すべての制御・変調方式の出力線間電圧パル スの周波数は $10 \mathrm{kHz}$ に統一して評価を行う†。ただし，電 流ヒステリシス制御は基本波出力の一周期間に渡って出力 線間電圧パルスの周波数が変化するので，その平均周波数 を $10 \mathrm{kHz}$ として評価する。図 10 に評価対象リアクトルの 概観を，表 2 に評価リアクトルの仕様を示す。本章および 4 章では図 10, 表 2 の左側の SK36M のリアクトルを評価 する。今回用いた鉄心材料の SK 材は高純度電解鉄粉であ

\footnotetext{
†インバータレグのスイッチング周波数とインバータの出力線間電 圧 $v_{\text {inv }}$ に現れるパルス電圧列の周波数は，常に等しいとは限らず，変 調方式によって異なる。本論では，インダクタに加わるパルス電圧列 の周波数が等しい条件で比較を行う関係で，それぞれの変調方式のス イッチング周波数ではなく，出力線間電圧 $v_{i n v}$ に現れるパルス電圧列 の周波数（本稿ではこれを「出力線間電圧パルスの周波数」と呼称す る）を同一にして評価を行った。
}

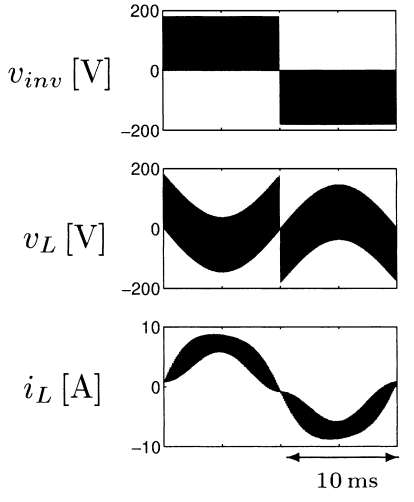

(a) USM

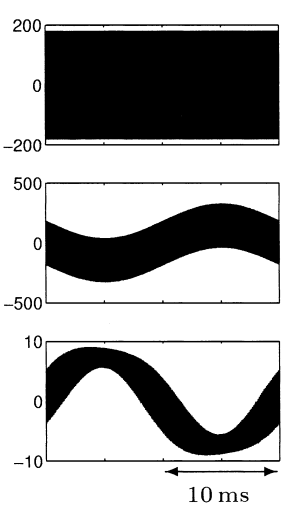

(b) BSM
図 11 サブハーモニック変調のシミュレーション 波形

Fig. 11. Simulation waveforms on sub-harmonic modulation.

り，飽和磁束密度は $1.6 \mathrm{~T}$ である。この SK 材は，スイッチ ング周波数が $10 \mathrm{kHz}$ 程度の周波数帯域では, 渦電流損や残 留損の影響は無視できるため，前節に示した鉄損算定法が そのまま利用できる。SK36M は定格運転時に最大磁束密 度が $0.83 \mathrm{~T}$ であり，コアの飽和磁束密度の $1 / 2$ 程度となる ように設計している。

電流ヒステリシス制御の鉄損算定では， $\Delta H$ と $H_{o}$ をシ ミュレーションで求め, パルス電圧毎の動的マイナールー プ面積を算定するのが理想的である。このとき, 精密なシ ミュレーションには $H_{o}$ の変化に対応した磁性体の比透磁 率の変化 (すなわちインダクタンスの変化) を加味する必要 があるが，今回は使用した回路シミュレータの制約上，比 透磁率の変動が無いもの（インダクタンス一定）として計 算している。すなわち, 理想リアクトルの条件で電流ヒス テリシス制御を行い，このときにリアクトルに加わる電圧 パルスから $\Delta B$ を算定してロスマップから損失を求めてい る。そのため, 後述するように, 電流ヒステリシス制御に おける損失算定結果は, 実測值との差異が若干大きくなっ ている。今後は磁気飽和に伴う比透磁率の変動を加味した 計算方法について検討を行う予定である。

〈3.2〉 鉄損の計算結果 図 11 に出力電力が約 $500 \mathrm{~W}$ 時のUSM, BSMのシミュレーション波形を, 図 12 にUSM, $\mathrm{BSM}$ のシミュレーション波形から鉄損算定法を用いて得 られたループ面積軌跡を示す。図 11 より, ユニポーラ変調 の USM よりもバイポーラ変調の BSM の方が明らかにリ プル電流が大きく鉄損が大きいことが予想できる。特にリ アクトル電流に含まれる出力周波数成分の電流值が小さい 領域においてリプル電流が大きい。これは図 12 のループ面 積軌跡から確認できる。USM よりも BSM の方が全体的に 動的マイナーループの面積が大きく，とりわけバイアス磁 界が低い領域において面積が大きくなっていることが分か る。実際に，(3) 式を用いてループ面積軌跡から計算される 動的マイナーループによる鉄損は USM で $8.275 \mathrm{~W}, \mathrm{BSM}$ で $25.81 \mathrm{~W}$ であり，鉄損に大きく差が生じ，ユニポーラ変 調よりもバイポーラ変調の方が動的マイナーループによる 鉄損が大きいことがわかる。

図 13 に出力電力が約 $500 \mathrm{~W}$ 時の UCM, BCM のシミュ 


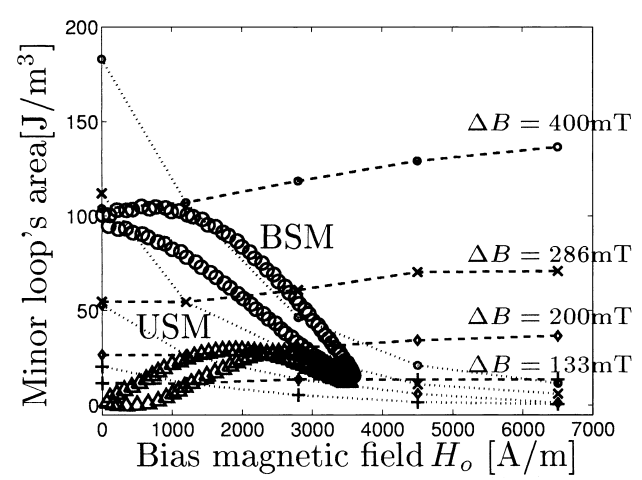

図 12 サブハーモニック変調のループ面積軌跡 Fig. 12. The loop area trajectory of sub-harmonic modulation on the loss map.

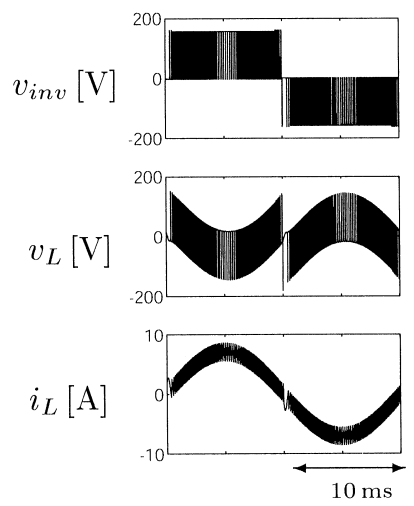

(a) USM

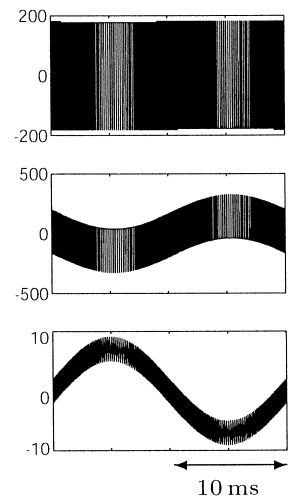

(b) BSM
図 13 電流ヒステリシス制御のシミュレーション 波形

Fig. 13. Simulation waveforms on current hysteresis control.

レーション波形を, 図 14 にUCM, BCM のシミュレーショ ン波形から鉄損算定法を用いて得られたループ面積軌跡を 示す。電流ヒステリシス制御は電流リプルが常に一定であ る制御であるため，ロスマップ上の特定の $\Delta H$ 一定の線 を辿る。サブハーモニック変調 (USM, BSM) と同様に, バイポーラ変調である BCM の方がユニポーラ変調である UCM よりも電流リプルが大きく, したがって, 動的マイナー ループの面積が大きいことが分かる。実際にループ面積軌 跡から計算される動的マイナーループによる鉄損は UCM で $5.70 \mathrm{~W}, \mathrm{BCM}$ で $20.51 \mathrm{~W}$ であり, バイポーラ変調の方 が鉄損が大きい。サブハーモニック変調，電流ヒステリシ ス制御の両制御方式においてもユニポーラ変調よりもバイ ポーラ変調の方が鉄損が相対的に大きくなることが提案し た鉄損算定法より明らかになった。

図 15 に，鉄損一出力電力特性の計算結果を示す。電流ヒ ステリシス制御では，鉄損算定の誤差が大きいので計算結 果にばらつきが見られるが, 平均的に見るとバイポーラ変調 (BSM, BCM) のほうが, ユニポーラ変調 (USM, UCM) に 比べて損失が大きいことがわかる。なお，UCM 変調では， 低出力領域の出力電流のゼロクロス付近において規定の電 流ヒステリシス幅制御が機能しない期間が生じるので出力

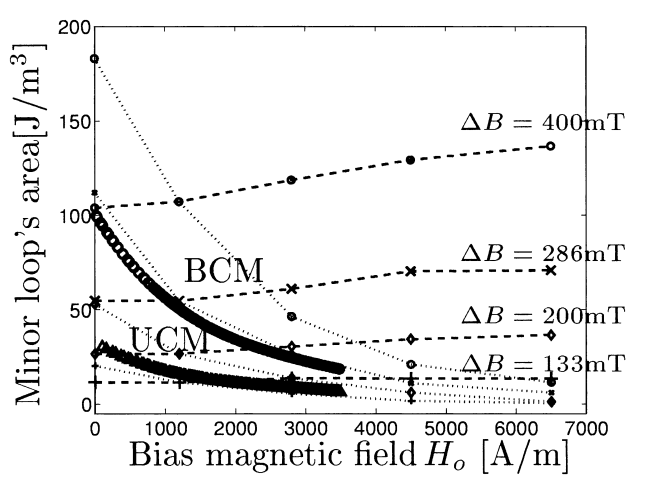

図 14 電流ヒステリシス制御のループ面積軌跡

Fig. 14. The loop area trajectory of the current hysteresis control on the loss map.

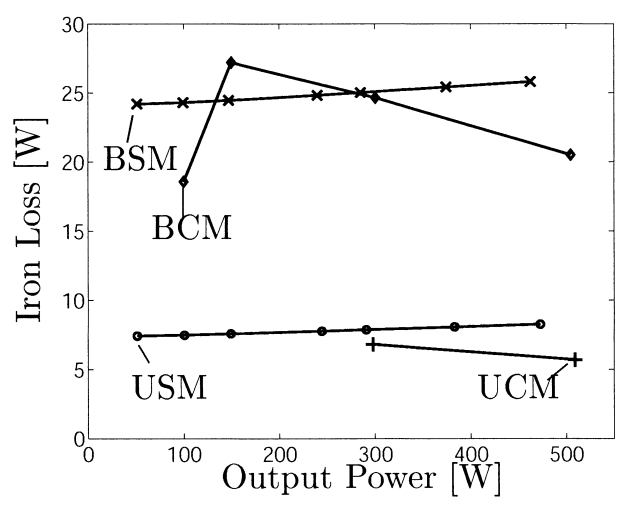

図 15 鉄損算定結果（鉄損一出力電力特性)

Fig. 15. Calculation result of iron loss-output power characteristics.

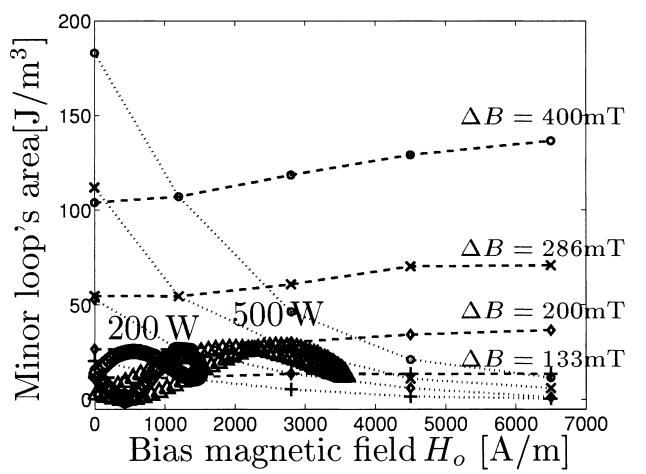

図 16 USM の出力電力の変化に伴うループ面積 軌跡の変化

Fig. 16. The loop area trajectory of the current hysteresis control on the loss map.

$300 \mathrm{~W}$ 以下における損失計算は行っていない。また，今回 の全ての変調方式において, 出力電力の増加に対して鉄損 は微増に留まっていることは注目すべき結果である。これ に関して，ループ面積軌跡と出力電力 (出力電流) の観点 から考察を加える。図 16 にインバータの変調方式がUSM において出力電力 $200 \mathrm{~W}$ 時と出力電力 $500 \mathrm{~W}$ 時のループ 面積軌跡を, 図 17 にインバータの变調方式がBSMにおい て出力電力 $200 \mathrm{~W}$ 時と出力電力 $500 \mathrm{~W}$ 時のループ面積軌 


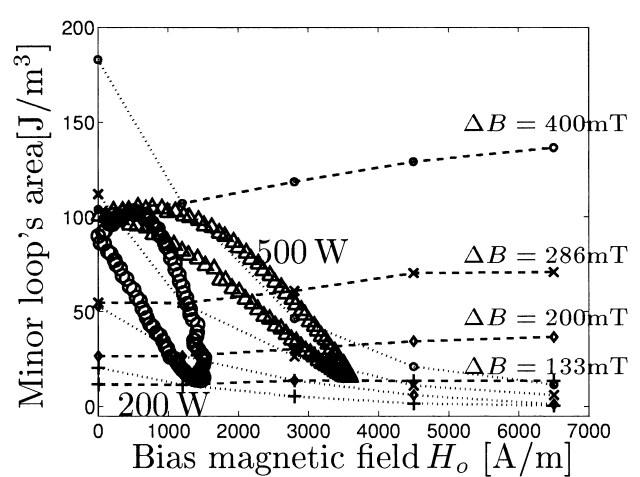

図 17 BSM の出力電力の変化に伴うループ面積 軌跡の変化

Fig. 17. The loop area trajectory of the current hysteresis control on the loss map.

跡を示す。出力電力すなわち出力電流が増加することによ り, 動的マイナーループのバイアス磁界 $H_{o}$ が増加し, ルー プ面積軌跡が横方向に伸びるが，各パルス電圧に対応する マイナーループ面積は増加しない。すなわち, 出力電流が 増加しても鉄損の顕著な増加につながらないことを示して いる。

\section{4. 実験検証}

$\langle 4 \cdot 1\rangle$ 鉄損の実験結果 前章の鉄損算定結果を実験 により検証する。主回路，フィルタリアクトルの条件は前 章のシミュレーション条件と同一の条件とする。鉄損，電 力变換効率の測定システムを図 18 に示す。入力電力, 出 力電力はパワーメータ (2533 横河電機製) で測定を行い, フィルタリアクトルの鉄損はリアクトルに二次巻線を施し， パワーメータ (PZ4000 横河電機製) で測定を行った。ス イッチ $\mathrm{Q}_{1}, \mathrm{Q}_{2}, \mathrm{Q}_{3}, \mathrm{Q}_{4}$ には, IGBT (2MBI50N-060 富士 電機製）を用いた。鉄損の基本波（メジャーヒステリシス） 成分は，リアクトルに同一の正弦波成分の電流を流したと きの鉄損を計測して求めた。

実験と前章の算定法により得られた動的マイナーループ による鉄損一出力電力特性を図 19 に示す。実験結果と計算 結果が概ね一致しているのが分かる。特にUSM と BSM の サブハーモニック変調に扔いて, 誤差が 10\%以内の精度で 動的マイナーループによる鉄損が算定できている。電流ヒ ステリシス制御に执いては，前節で述べた理由により誤差 が若干大きいが，それでも 10\%〜20\%程度に収まっている。

$\langle\mathbf{4} \cdot \mathbf{2}\rangle$ 電力变換効率と損失分析 図 20 に電力変換効 率一出力電力特性を示す。サブハーモニック変調, 電流ヒス テリシス制御の両方式に扔いてバイポーラ変調よりもユニ ポーラ変調の方が電力変換効率が高く, 最大定格の $500 \mathrm{~W}$ 時で約 4\%の違いが生じた。図 21 にダイオード，IGBT な どの半導体の損失-出力電力特性を示す。半導体の損失は 全損失から鉄損と銅損を除算することにより算出した。厳 密にはフィルタ用コンデンサからも損失が生じるが，他の 損失と比べて十分小さいため，この損失は無視できるもの とする。銅損は同一のコア形状，巻線形状を持つ空芯リア クトルを用いて測定した。空芯リアクトルを用いた銅損測

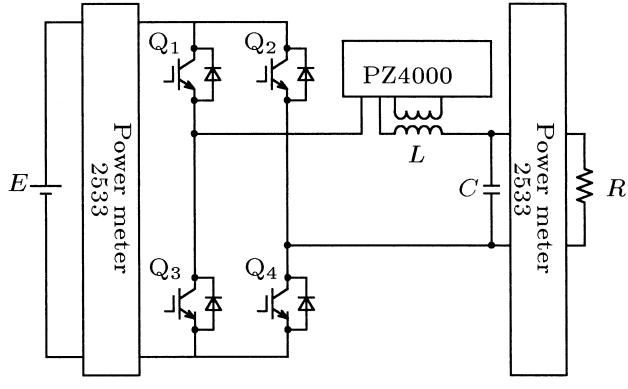

図 18 PWM インバー夕測定回路構成

Fig. 18. Circuit configuration.

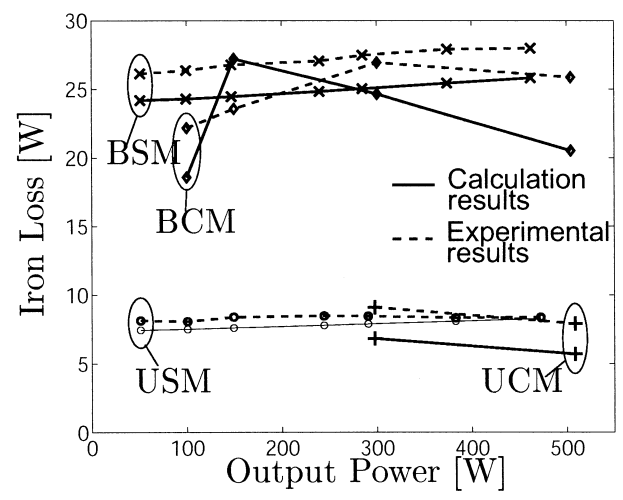

図 19 実験結果と計算結果の比較

Fig. 19. Comparison of experimental result and calculation result.

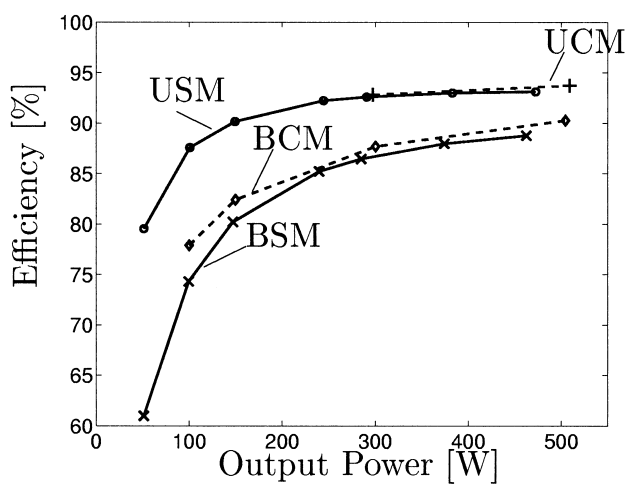

図 20 実験回路全体の変換効率-出力電力特性

Fig. 20. Total efficiency of experimental circuit-output power characteristics.

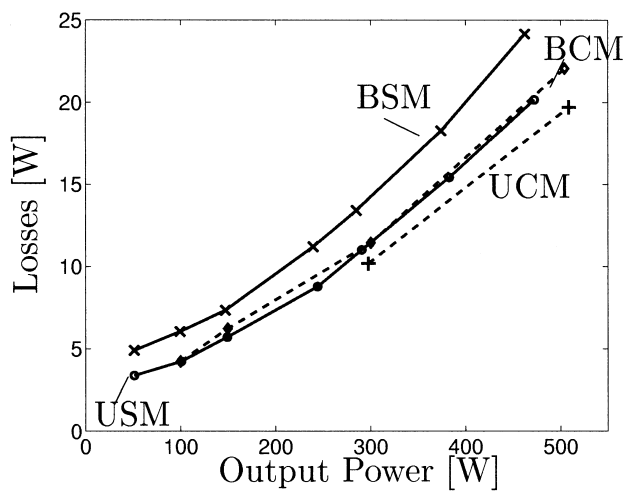

図 21 半導体による損失一出力電力特性

Fig. 21. Semi-conductor loss-output power characteristics. 


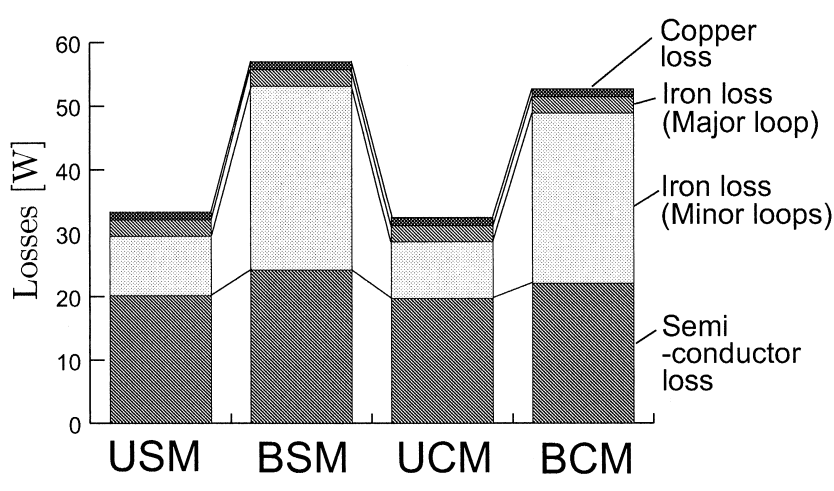

図 22 各制御方式の出力電力 $500 \mathrm{~W}$ 時の損失比較

Fig. 22. Comparison of loss on each inverter control when the output power is $500 \mathrm{~W}$.

定法の詳細については文献(12) を参照されたい。図 21 よ り, サブハーモニック変調, 電流ヒステリシス制御の両方 式に扔いてユニポーラ変調よりもバイポーラ変調の方が半 導体による損失が大きい。出力線間電圧パルスの周波数は 両者とも $10 \mathrm{kHz}$ であるが, IGBT のターンオン, ターンオ フ損失と還流ダイオードのリカバリ損失はバイポーラ変調 はユニポーラ変調より多くなることに起因する。図 22 に 最大定格の約 $500 \mathrm{~W}$ 時の損失分析結果を示す。制御・变調 方式の違いによる半導体損失の違いよりも，動的マイナー ループによる鉄損の違いの方が電力変換効率に影響してい ることが分かる。

\section{5. コアの最大磁束密度と鉄損・電力変換効率の関係}

フィルタリアクトルの設計は技術者の経験則に頼るとこ ろが大きい。とりわけコアの動作時の最大磁束密度をどれ だけとるかは技術者の経験則で決まるといっていい。動作 時のコアの最大磁束密度を大きくすることはリアクトルの 小型・軽量化につながるため, 今後, 高パワー密度化を見 据えれば，フィルタリアクトルの動作時の最大磁束密度に 関する議論は重要と考える。3 章と 4 章の計算結果と実験 結果より, 出力電流および出力電力を変化させても動的マ イナーループによる鉄損はほぼ変化しなかった。このこと から，コア寸法を小型化して, 最大磁束密度を増加させて も動的マイナーループによる鉄損は極端に増加しないこと が予想される。

本章では, 図 10 と表 2 に示す異なる体積を持つSK36M と SK28M を用いて, 最大磁束密度が異なるリアクトルを製 作し，その鉄損，銅損，および半導体による損失を比較する。 SK28M を用いたリアクトルは，定格 $500 \mathrm{~W}$ 運転時の最大 磁束密度は $1.07 \mathrm{~T}$ であるが，通常はコアの飽和を避けるた めに最大磁束密度はこの值よりも小さく設計する。最大磁 束密度を SK36M の $0.83 \mathrm{~T}$ から SK28M の $1.07 \mathrm{~T}$ にするこ とにより，表 2 より体積は $46546 \mathrm{~mm}^{3}$ から $12452 \mathrm{~mm}^{3}$ に， 重量は $340 \mathrm{~g}$ から $90 \mathrm{~g}$ になり，体積・重量は約 $1 / 4$ になる。 (3) 式より, 動的マイナーループ面積の総和に基本波の出力 周波数とコアの体積を乗算した值が鉄損 $[\mathrm{W}]$ となるため, 動的マイナーループーつあたりの面積が増加しても，一つ

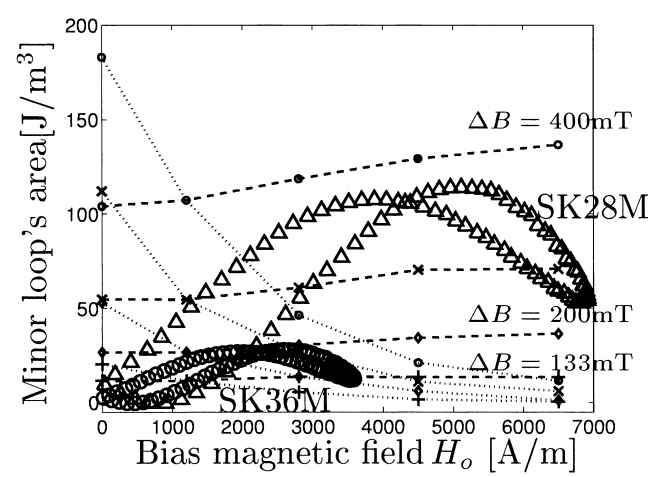

図 23 USM 時の SK36M と SK28M のループ 面積軌跡

Fig. 23. The loop area trajectory of the SK $36 \mathrm{M}$ and the one of the SK28M under USM.

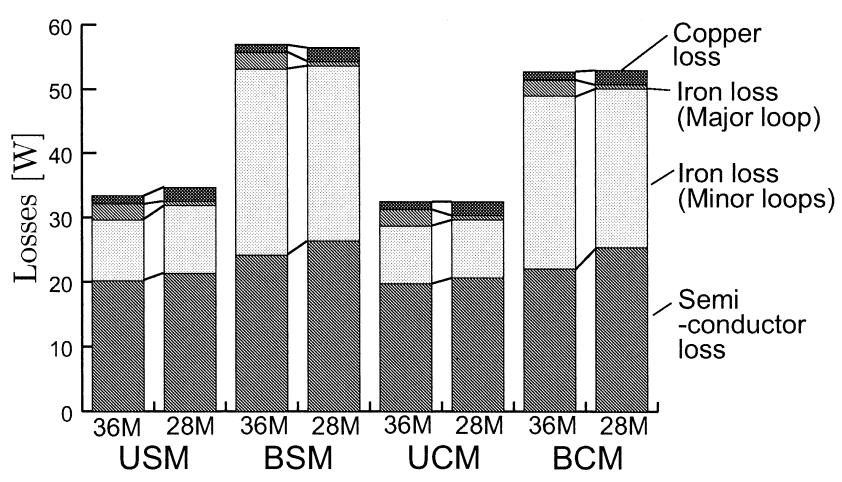

図 $24 \mathrm{SK} 36 \mathrm{M}$ と $\mathrm{SK} 28 \mathrm{M}$ の $500 \mathrm{~W}$ 時の損失比較

Fig. 24. Comparison of loss on each inverter control when the output power is $500 \mathrm{~W}$.

のリアクトルとしての動的マイナーループの鉄損は極端に 増加しないことが期待される。図 23 に変調方式をUSM と した場合の SK36M と SK28M のシミュレーション波形か ら得られたループ面積軌跡を示す。SK28M の方がSK36M よりも出力線間電圧パルス毎の $\Delta B$, 動的マイナーループ の面積が増加しているのがわかる。しかし, リアクトル単 体の鉄損の測定結果は SK36M のときに $8.275 \mathrm{~W}, \mathrm{SK} 28 \mathrm{M}$ のときに $9.123 \mathrm{~W}$ であり, $10.24 \%$ の増加に留まり, 当初の 予想に沿った結果が得られた。

図 24 にインバータの制御方式をUSM, BSM, UCM, BCM とした場合の出力電力 $500 \mathrm{~W}$ 時の実験結果から得ら れた損失比較結果を示す。すべての制御・变調方式において, SK36M と SK28M の動的マイナーループによる鉄損がほ ぼ同じであることが分かる。また，SK28M の時はSK36M の時より, 半導体損失が増加しているのが分かる。SK28M はバイアス磁界の大きい領域まで達するので, リアクトル のインダクタンスが低下し, リプル電流が増加し, スイッチ ング損と導通損が増加したと考えられる。しかし，SK28M の方がメジャーヒステリシスループ (正弦波) による鉄損 が小さい。結果として, 小形のコア材を使用しても, 今回 の制御・変調方式の範囲では, ほほ同等の電力変換効率を 維持できることがわかる。 


\section{6. まとめ}

本稿では，フィルタリアクトルの動的マイナーループと 鉄損について論じ, 磁性体ロスマップと PWM インバータ 用リアクトルの鉄損算定法を提案した。代表的な制御方式 であるサブハーモニック変調，電流ヒステリシス制御につ いて，それぞれユニポーラ変調とバイポーラ変調を組み合 わせ, 合計 4 種類の変調制御方式における動的マイナールー プによる鉄損を計算し，実験結果と比較・検証を行った。 鉄損算定法により，動的マイナーループによる鉄損がサブ ハーモニック変調の場合で，10\%以内の誤差で計算できる ことが明らかになった。また鉄損算定法と実験により，サ ブハーモニック変調と電流ヒステリシス制御の両方式にお いてユニポーラ変調よりもバイポーラ変調の方が格段に鉄 損が大きくなることが分かった。また鉄損算定法により求 めたループ面積軌跡は, 各制御方式の鉄損を比較する上で, 有用な指標となることを示した。最後に同一の材質で異な る体積を持つコアを用いたリアクトルについて，鉄損と銅 損，および半導体損失を実験結果に基づいて比較・検証し た。動作時の最大磁束密度を通常よりも大きく設計するこ とで,リアクトルの体積・重量を減少でき, 同等の電力変 換効率が得られることを示した。

(平成 18 年 3 月 13 日受付, 平成 18 年 8 月 31 日再受付)

\section{文献}

(1) H. Ohashi: "Recent Power Device Trend-Technical Review—", J. IEE Japan, Vol.122, No.3, pp.168-171 (2002-3) (in Japanese) 大橋弘通:「最新のパワーデバイスの動向」, 電学誌, 122, 3, pp.168-171 (2002-3)

(2) M. Amar and R. Kaczmarek: "A General Formula for Prediction of Iron Losses Under Non sinusoidal Voltage Waveform", IEEE Trans. Magnetics, Vol.31, No.5, pp.2504-2508 (1995)

(3) Y. Chen and P. Pillay: "An Improved Formula for Lamination Core Loss Calculations in Machines Operating with High Frequency and High Flux Density Exicitation", in Conf. Rec. IEEE-IAS Annu. Meeting, Vol.2, pp.759$766(2002-10)$

(4) P. Tenant and J.J. Rousseau: "Dynamic Model of Magnetic Materials Applied on Soft Ferrites", IEEE Trans. Power Electronics, Vol.13, pp.372-379 (1998)

(5) V.J. Thottuvelil, T.G. Wilson, and H.A. Owen: "High Frequency Measurement Techniques for Magnetic Cores", IEEE Trans. Power Electronics, Vol.5, pp.41-53 (1990)

(6) A. Boglietti, P. Ferraris, M. Lazzari, and F. Profumo: "Effects of Different Modulation Index on the Iron Losses in Soft Magnetic Materials Suppulied by PWM Inverter", IEEE Trans. Magnetics, Vol.29, No.6, pp.3234-3236 (1993)

( 7 ) A.J. Moses and N. Tutkun: "Investigation of Power Loss in Wound Toroidal Cores under PWM Excitation", IEEE Trans. Magnetics, Vol.33, No.5, pp.3763-3765 (1997)
(8) A. Boglietti, P. Ferraris, M. Lazzari, and M. Pastorelli: "Influence of Modulation Techniques on Iron Losses with Single Phase DC/AC Converters", IEEE Trans. Magnetics, Vol.32, No.5, pp.4884-4886 (1996)

(9) A. Boglietti, P. Ferraris, M. Lazzari, and M. Pastorelli: "About the Possibility of Defining a Standard Method for Iron Loss Measurement in Soft Magnetic Materials with Inverter Supply", IEEE Trans. Industry Applications, Vol.33, No.5, pp.1283-1288 (1997)

(10) T. Shimizu, K. mishima, K. Wada, and K. Ishii: "Mitigation of Inductor Loss Based on Minor-Loop Hysteresis Characteristics", IEICE/IEEE INTELEC, pp.834-839 (2003)

(11) K. Mishima, K. Wada, and T. Shimizu: "Iron Loss Evaluation of the AC Filter Inductor for PWM Inverter", IEEJ Proc. of Technical Meeting, SPC03-34, pp.49-54 (2003) (in Japanese)

三島健太郎・和田圭二・清水敏久：「単相電圧形 PWM インバータ 回路に抢けるフィルタ用リアクトルの鉄損評価」, 半導体電力変換研 資, pp.49-54 (2003)

(12) S. Iyasu, T. Shimizu, and K. Ishii: "A Novel Inductor Loss Calculation Method on Power Converters Based on Dynami minor loop", IEEJ IPEC, pp.2016-2022 (2005)

居 安 誠 二 (学生員) 1981 年 8 月 20 日生。 2006 年 3 月東

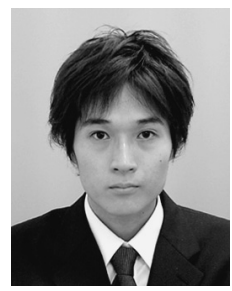
京都立大学大学院工学研究科修士課程電気工学専 攻修了。同年 4 月（株）デンソー入社，現在に至 る。在学中はフィルタリアクトルの鉄損の研究に 従事。

清 水 敏 久（上級会員） 1955 年 11 月 29 日生。1 1980 年 3 月

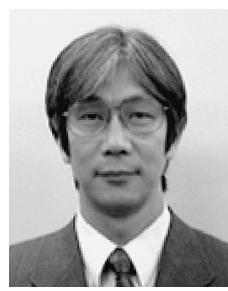
東京都立大学大学院工学研究科修士課程電気工学 専攻修了。同年 4 月富士電機 (株) 入社。1993 年 4 月東京都立大学大学院工学研究科電気工学専攻 助教授。現在, 首都大学東京 (旧, 東京都立大学) 理工学研究科教授。工学博士。パワーエレクトロ ニクスに関する研究に従事。1999 年電気学会論 文賞受賞。IEEE Senior Member。

石 井謙市朗 (正員) 1967 年 3 月 27 日生。 1990 年 3 月日本

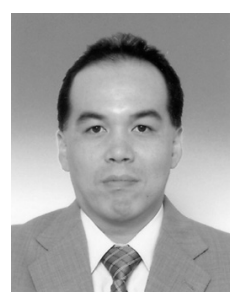
大学理工学部電気工学科卒業。同年 4 月東邦亜鉛 (株) 入社, 現在に至る。リアクトル，ノイズフィ ルタの研究開発に従事。 